Vol 11, Issue 3, 2018

\title{
ANTI-ULCER ACTIVITY OF AFRICAN LEAVES (VERNONIA AMYGDALINA DEL.) ETHANOL EXTRACT ON MALE RAT
}

\author{
WAHYUDI $^{1}$, EDY SUWARSO ${ }^{1}$, MARLINE NAINGGOLAN ${ }^{2 *}$ \\ ${ }^{1}$ Department of Pharmacology, Faculty of Pharmacy. ${ }^{2}$ Department of Pharmaceutical Biology, Faculty of Pharmacy, Universitas Sumatera \\ Utara, Medan, Indonesia. Email: linegolan57@gmail.com
}

Received: 10 November 2017, Revised and Accepted: 14 December 2017

\begin{abstract}
Objectives: This study aims to evaluate the anti-ulcer activity of African leaves (Vernonia amygdalina Del.) ethanol extract on male rat.

Methods: African leaf powder was extracted used ethanol $96 \%$ by percolation, then made into a suspension preparation used $0.5 \%$ Na-CMC with 3 dose variations $(100,200$ and $400 \mathrm{mg} / \mathrm{kg})$. Further tested its effectiveness in healing peptic ulcer in gastric-induced rats using acetosal dose $800 \mathrm{mg} / \mathrm{kg}$ with oral administration every day until surgery at 3, 8, and 14. Observations include macroscopic (number and index of ulcer) and microscopic (histopathological test).
\end{abstract}

Results: A significant healing of ulcer was observed. The extract 100,200 , and $400 \mathrm{mg} / \mathrm{kg}$ group showed significant ( $\mathrm{p}<0.05$ ) reduction in number and index of ulcer as compared to the negative control. The most effective dose is $200 \mathrm{mg} / \mathrm{kg}$ because it has the greatest ability to reduce the number and index of ulcers and has the fastest recovery day.

Conclusion: Results of this study indicated that African leaves (V. amygdalina Del.) ethanol extract has potential anti-ulcer activity.

Keywords: African leaves, Peptic ulcer, Acetosal, Vernonia amygdalina Del.

(C) 2018 The Authors. Published by Innovare Academic Sciences Pvt Ltd. This is an open access article under the CC BY license (http://creativecommons. org/licenses/by/4. 0/) DOI: http://dx.doi.org/10.22159/ajpcr.2018.v11i3.23565

\section{INTRODUCTION}

Multiple factors and harmful substances continuously exposed to the gastric mucosa that may trigger the onset of peptic ulcers, this being the most prevalent gastrointestinal disease worldwide [1]. About 14.5 million people worldwide are estimated affected by peptic ulcers with 4.08 million deaths per year [2].

Peptic ulcers are wound on the mucosal layer (epithelial layer) of the gastric and mucosal irritation with diameter $5 \mathrm{~mm}$ or more in depth down to submucosa. The pathogenesis of peptic ulcers occurs when there is an imbalance between aggressive and defensive factors [3]. Among the defensive factors, we can include mucus and bicarbonate production, cellular regeneration, and adequate blood flow, while the main aggressive factors comprise gastric acid, pepsin secretion, and reactive oxygen species [4].

Herbal medicine is one of the other ways of treatment outside the medical science, and traditional medicine needs to be fostered, developed, and supervised to be accountable for its benefits and safety [5]. Herbal medicine in Indonesia is a nation's cultural heritage, so it needs to be explored, researched, and developed to be used more widely by the community. Tropical Indonesia has the second largest biodiversity in the world after Brazil has about 25,000-30,000 plant species that makeup $80 \%$ of all plant species in the world and $90 \%$ of all Asian plants [6].

Vernonia amygdalina Del. or African leaf is bushes originating from the African and other parts of Africa, especially Nigeria, Cameroon, and Zimbabwe. These plant can be found in the yard, along rivers and lakes, and in the forests [7]. These plants contain flavonoids, tannins, saponins, and terpenoids [8]. Tannin has an antimicrobial effect that can help defend against Helicobacter pylori. In addition, tannins can also precipitate microprotein at the site of the ulcer to form a thin protective layer that prevents the attack of irritant factors of proteolytic enzymes [9]. Saponin activates the protective factor of mucous membranes [10]. Flavonoids improve mucosal blood circulation and increase prostaglandins, but the most important is its role as an antioxidant that will counteract free radicals that play a role in the pathogenesis of peptic ulcers [11].

Based on the use of African leaves in the community and the pharmacological effects produced by compounds contained in African leaves, this is the underlying importance of the authors to conduct research with the title "Testing the effectiveness of African leaf ( $V$. amygdalina Del.) ethanol extract for peptic ulcer healing on male rats."

\section{MATERIALS AND METHODS}

Materials

Drugs and chemicals used in this study were Aquades, ethanol 96\%, acetosal $100 \mathrm{mg}$ (generic), formalin, Na, CMC, Na2HPO4, NaH2PO4, $\mathrm{NaOH} 0.01 \mathrm{~N}$, methyl red indicator, phenolphthalein indicator, and sucralfate (Propepsa ${ }^{\circledR}$ ).

\section{Preparation of extracts}

V. amygdalina Del. was collected from Meunasah Teungoh village, Nurussalam subdistrict, East Aceh District, Nanggroe Aceh Darussalam Province, Indonesia. The leaves were washed and dried at $30^{\circ} \mathrm{C}-35^{\circ} \mathrm{C}$, then grind until dried powder was obtained. The dried powder was percolated using ethanol 96\%, then the obtained percolate was evaporated and freeze-dried.

\section{Animals}

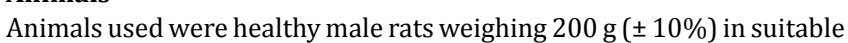
cages, given appropriate food and drink, and acclimatized for 2 weeks before being treated. Before rat treatment is fasted for $24 \mathrm{~h}$ with the aim of obtaining a relatively clean gastric from food. 
Preparation of Na-CMC suspension $0.5 \%$

A total of $0.5 \mathrm{~g} \mathrm{Na}-\mathrm{CMC}$ is sown in a mortar containing $\pm 10 \mathrm{ml}$ of hot distilled water, silenced for $15 \mathrm{~min}$, then crushed until a transparent mass is obtained, then crushed until homogeneous, diluted with distilled water, homogenized, and fed into a $100 \mathrm{ml}$ tin flask, sufficient volume with distilled water to the mark line.

\section{Preparation of African leaf ethanol extract (ALEE) suspension}

Each extract was prepared with NA-CMC 0.5\% with different doses, 100,200 , and $400 \mathrm{mg} / \mathrm{kg}$. Each dose was weighed and mixed with $\mathrm{Na}-$ CMC $0.5 \%$ to homogeneous to $10 \mathrm{ml}$ volume.

\section{Preparation of acetosal suspension}

Weigh the acetosal tablet equivalent to $800 \mathrm{mg}$, insert in the mortar, added $0.5 \mathrm{~cm} \mathrm{Na-CMC}$ to the homogeneous, and then, the volume is $10 \mathrm{ml}$

\section{Induction of peptic ulcer}

Rat was given an acetosal dose of $800 \mathrm{mg} / \mathrm{kg}$ for 2 days, $2 \mathrm{~h}$ after induction rats divided into 6 groups. Group I of 3 induced rats will be completely dissected and considered to be the initial condition of gastric ulcers. Groups II, III, IV, V, and VI each consist of 3 subgroups (days 3, 8, and 14).

- Group I: Control peptic ulcer

- Group II: No treatment (negative control)

- Group III: Treated with sucralfate $360 \mathrm{mg} / \mathrm{Kg}$ (positive control)

- Group IV: Treated with $100 \mathrm{mg} / \mathrm{Kg}$ of ALEE orally

- Group V: Treated with $200 \mathrm{mg} / \mathrm{Kg}$ of ALEE orally

- Group VI: Treated with $400 \mathrm{mg} / \mathrm{Kg}$ of ALEE orally.

All the rats in each group were treated daily, and then, the animals were sacrificed on the $3^{\text {rd }}, 8^{\text {th }}$, and $14^{\text {th }}$ days.

\section{Macroscopic observation}

Before treatment rats are fasted for $24 \mathrm{~h}$ without food, but still beverages. The rats are sacrificed by dislocation. The rats were dissected for his stomach and then opened and observed the occurrence of ulcers in the rat's stomach.

Macroscopic observations included observations of the number of peptic ulcers and the index of ulcers. Observation of peptic ulcers is done by visually observing the number of ulcers formed in the gastric. The calculated gastric ulcer is then measured in length and width using a sliding term which then the data will be used for the calculation of the peptic ulcer index by the following formula [12]

\footnotetext{
Total area of ulcer

Total area of gastric mucosa $\times 100$
}

\section{Microscopic observation}

The histological observation of gastric mucosal is performed using a light microscope with $10 \times 10$ and $10 \times 40$ magnification.

\section{RESULT}

The observed data on the average number of ulcers for each group are shown in Table 1. Conditions at the beginning of ulcers (Day 0) indicate the formation of 7 peptic ulcers. The decrease in the number of peptic ulcers can be seen on the $3^{\text {rd }}$ day which occurs in all treatment groups. The smallest ulcers on the $3^{\text {rd }}$ day started from the positive control group and ALEE $200 \mathrm{mg}$ (3.33 ulcers), ALEE $400 \mathrm{mg}$ (3.66 ulcers), ALEE $100 \mathrm{mg}$ (4 ulcers), and without treatment (4.66 ulcers).

Positive control group, ALEE 200 and $400 \mathrm{mg}$ showed healing on the $8^{\text {th }}$ day, and visual observation showed no more ulcers in rat stomach. Gastric ulcers were present on the day 8 in the ALEE $100 \mathrm{mg}$ ( 0.66 ulcers) and without treatment (2.33 ulcers). Healing of peptic ulcers on day 14 was shown in the positive control group, ALEE 100, 200 and $400 \mathrm{mg}$. The untreated group still showed a gastric ulcer (1.33 ulcers) until day 14 .
Macroscopic observation is also done by calculating the index of peptic ulcer in each group. The result of calculation of the mean peptic ulcer index is shown in Table 2.

Index ulcers in the 0 day gastric ulcer control group were 2.00, considered the initial condition of peptic ulcers. The decrease in the index of ulcers occurred starting on the $3^{\text {rd }}$ day with the greatest decrease starting from the positive control group (0.95), ALEE $200 \mathrm{mg}$ (1.47), ALEE $100 \mathrm{mg}$ (1.54), ALEE $400 \mathrm{mg}$ (1.64), and the group without treatment (1.50). The decline in the index value of peptic ulcers showed that giving of ALEE was able to reduce the severity of gastric ulcers that occurred in rat stomach. The graph of the decrease in the peptic ulcer index can be seen in Fig. 1.

The decrease in gastric ulcer index can be seen in Fig. 1, where on the $8^{\text {th }}$ day, the positive control group, ALEE $200 \mathrm{mg}$, and ALEE $400 \mathrm{mg}$, the value of the gastric index has 0 . The ALEE group of $100 \mathrm{mg}$ and without treatment on $8^{\text {th }}$ day still had an index of ulcers 0.22 and 1.48. The gastric ulcer index at day 14 became 0 in the positive control group, ALEE 100, 200, and $400 \mathrm{mg}$, while the untreated group had not shown a cure with a gastric index of 0.42 .

Based on statistical results using one-way ANOVA method, there was a significant difference $(\alpha \leq 0.05)$ to data of amount and index of peptic ulcer on days 3,8 , and 14 . This shows that ALEE suspension preparation has a healing effect of peptic ulcer. Then proceed with post hoc Tukey honestly significant difference test to see the real difference of each rat treatment. The results of the post hoc Tukey test show that the three ALEE suspension preparations show significantly different results than the negative controls.

Microscopic observations were performed by histopathologic tests on rat stomach tissue. The result histopathologic test of rat's gastric with $10 \times 10$ magnification can be seen in Fig. 2. Histopathological test results in gastric mucosa of rats administered by sucralfate and suspension of ALEE showed that mucosal cell cohesion was good and there was no erosion of epithelial cells on the day 14

\section{DISCUSSION}

Orally, administration of acetosal doses $800 \mathrm{mg} / \mathrm{kg}$ for 2 days may form peptic ulcers, and this can be visually observed on the surgical stomach and evidenced by the erosion of gastric mucosal cells seen in the histology induced rat. Acetosal can cause ulcers by damaging the gastric mucosal defenses and systemic inhibition of gastric mucosal protectors through inhibition of cyclooxygenase activity [13]. The use of nonsteroidal anti-inflammatory drugs (NSAIDs) over long periods induces gastric ulcer development through the suppression of prostaglandin synthesis [14]. Prostaglandins have an integral role

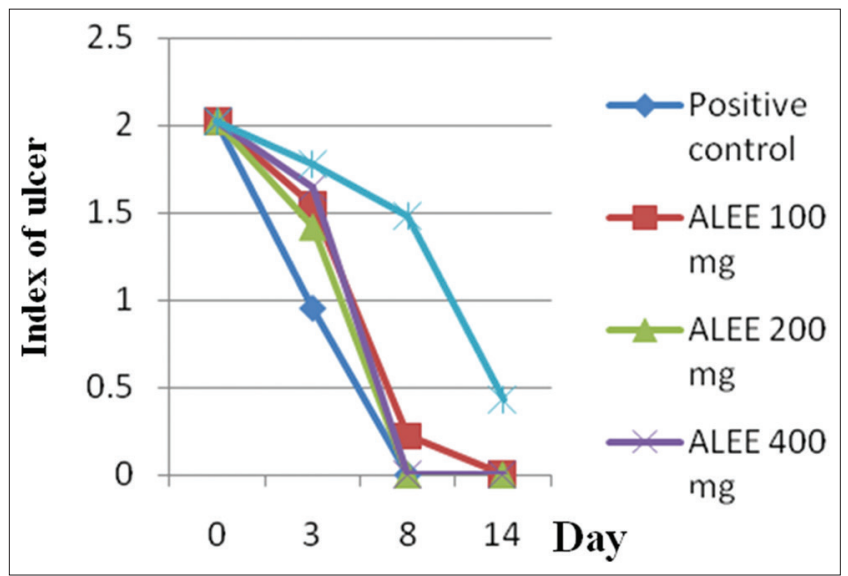

Fig. 1: Effect of the African leaf ethanol extract on the peptic ulcer index 
Table 1: Effect of the ALEE on number of ulcers

\begin{tabular}{lllllll}
\hline Day & Control ulcer & Negative control & Positive control & ALEE 100 mg & ALEE 200 mg & ALEE 400 mg \\
\hline 0 & $7.00 \pm 1.00$ & - & - & - & - & - \\
3 & - & $4.66 \pm 0.57$ & $3.33 \pm 0.57$ & $4.00 \pm 2.00$ & $3.33 \pm 1.52$ & $3.66 \pm 1.15$ \\
8 & - & $2.33 \pm 0.57$ & 0 & $0.66 \pm 0.57$ & 0 & 0 \\
14 & - & $1.33 \pm 1.15$ & 0 & 0 & 0 & 0 \\
\hline
\end{tabular}

$\mathrm{Al}$ the values are express as mean \pm SD. SD: Standard deviation, ALEE: African leaf ethanol extract

Table 2: Effect of the ALEE on index of ulcers

\begin{tabular}{lllllll}
\hline Day & Control ulcer & Negative control & Positive control & ALEE 100 mg & ALEE 200 mg & ALEE 400 mg \\
\hline 0 & $2.00 \pm 0.22$ & - & - & - & - \\
3 & - & $1.77 \pm 0.04$ & $0.95 \pm 0.13$ & $1.53 \pm 0.44$ & $1.41 \pm 0.52$ \\
8 & - & $1.48 \pm 0.08$ & 0 & $0.21 \pm 0.21$ & 0 \\
14 & - & $0.42 \pm 0.38$ & 0 & 0 & 0 \\
\hline
\end{tabular}

Al the values are express as mean \pm SD. SD: Standard deviation, ALEE: African leaf ethanol extract

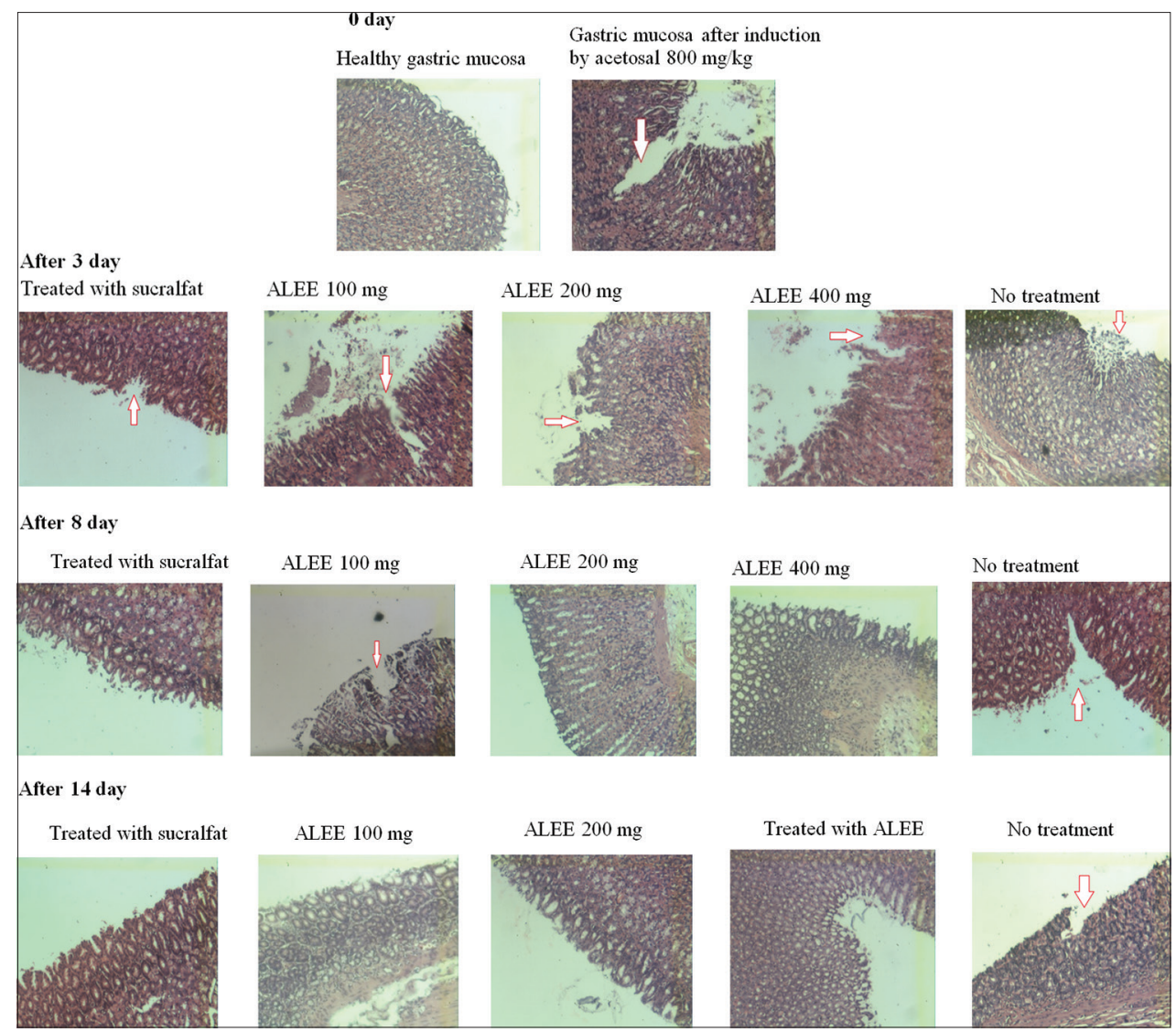

Fig. 2: Histology of rat gastric mucosa after treatment

in stomach protection through stimulation of mucus and bicarbonate secretion and promotion of blood flow and proliferation of epithelial cells. NSAIDs are the second most common cause of gastric ulcers, particularly in seniors [15].

The healing effect of the positive control group is caused by the ability of sucralfate at the acidic atmosphere to form a viscous paste selectively binding at the base of the ulcer and becomes a barrier that protects the ulcer against the diffusion of acids, pepsin, and bile salts (local protection). Sucralfate also has cytoprotection properties by increasing the production of prostaglandins as well as stimulating the secretion of mucus and bicarbonate [16].

The healing effects of gastric ulcers that occur in the ALEE group of 100, 200 , and $400 \mathrm{mg}$ are caused by flavonoid, saponin, and tannin contents that play a role in the healing of peptic ulcers [17]. Sayed et al. reported that flavonoids and tannins in Vitis vinifera leaves have antioxidant activity which play a role in the healing of peptic ulcers [18]. Flavonoids and tannins are among the active compounds in plants that can provide protection against gastric ulcers by acting as a protective (protective) gastric factor [19]. Flavonoids are natural phenolic compounds with a low molecular weight that has a wide range of biological effects, including gastric anti-stomach activity [20].

Tanin is known to have styptic properties and is the ability to react with proteins in the tissues of the gastric mucosa. Its ability is useful for coating the outer layer of mucosa that makes it less permeable and more resistant to ulcers or irritation. The healing effects of peptic ulcers from tannins are to form microprotein deposits at the site of ulceration to form a protective layer that makes them more resistant to 
biological and chemical irritation [21]. Tannins have astringent activity by stimulating protein precipitating and vasoconstriction resulting information of impenetrable protective barrier preventing gastric ulcer by reducing the number of ulcer. Saponin can activate mucous membrane protective elements [22].

\section{CONCLUSION}

Based on the results of this study, it can be concluded that ALEE has a healing effect of gastric ulcers because it can reduce the number and index of peptic ulcers and can restore gastric mucosal cell cavity damaged by peptic ulcer.

The results can be more accurately assessed by either involving a larger sample size or using a higher concentration of the extract.

\section{ACKNOWLEDGMENTS}

The authors gratefully acknowledge to all the parties involved in this research, especially to all pharmacology laboratory staff of the pharmacy faculty of Universitas Sumatera Utara.

\section{REFERENCES}

1. Sumbul S, Ahmad MA, Asif M, Akhtar M. Role of phenolic compounds in peptic ulcer: An overview. J Pharm Bioallied Sci 2011;3:361-7.

2. Junior IF, Balogun SO, Oliveira RG, Damazo AS, Martins DT. Piper umbellatum L.: A medicinal plant with gastric-ulcer protective and ulcer healing effects in experimental rodent models. J Ethnopharmacol 2016;41:30435-4

3. Suhatri, Rusdi, Sugesti E. Effect of carrot decoction on the gasric ulcer of white male rats. J Sains Farmasi dan Klinis 2015;2:99-103.

4. Malfertheiner P, Chan FK, McColl KE. Peptic ulcer disease. Lancet 2009;374:1449-61.

5. Ministry of Health of Republic of Indonesia. Decree of the Minister of Health of the Republic of Indonesia Number 1076/Menkes/SK/ VII/2003 About the Implementation of Traditional Medicine. Jakarta: Kemenkes; 2003.

6. Budianto WE. Ethanol extract turmeric (Curcuma domestica val) in preventing an increased gastric acidity rattus novergicus which induced by histamine. J Ilm Kedokteran 2014;3:

7. Yeap K, Hoyong W, Beh K, Liang S, Ky H, Yousr N, et al. Vernonia amygdalina. an ethnoveterinary and etnomedical used green vegetable with multiple bioactivity. J Med Plants Res 2010;4:2787-812.

8. Ohigashi H, Koshimizu K, Huffman MA. Use of Vernonia amygdalina by wild chimpanzee: Possible roles of its bitter and related constituens. Physiol Behav 1994;55:1209-16.

9. Sofidiya M, Agufobi L, Aj A, Olowe JA, Familoni OB. Effect of Flabellaria paniculata cav. Extracts on gastric ulcer in rats. Complementary Altern Med 2012;1:168-73.

10. Ebadi M. Pharmacodynamic Basis of Herbal Medicine. Florida: CRC Press LLC; 2002.

11. Lira MS, Dias GE, Pinto ME, Lima CA, Ferreira AL, Brito AR. Flavonoids with gastroprotective activity. Molecules 2009;14:979-1012.

12. Sabiu S, Garuba T, Sunmonu T, Ajani E, Sulyman A, Nurain I, et al. Indomethacin-induced gastric ulceration in rats: Protectiveroles of Spondias mombin and Ficus exasperate saheed. Toxicol Rep 2015;2:261-7.

13. Botting RM. Inhibitors of cyclooxygenases: Mechanisms, selectivity and uses. J Physiol Pharmacol 2006;57 Suppl 5:113-24.

14. Wallace JL. Nonsteroidal anti-inflammatory drugs and the gastrointestinal tract. Mechanisms of protection and healing: Current knowledge and future research. Am J Med 2001;110:19S-23S.

15. Harris A, Misiewicz JJ. ABC of the upper gastrointestinal tract. Management of helicobacter pylori infection. BMJ 2001;323:1047-50.

16. Greer D. Peptic ulcer disease pharmacological treatment. Hosp Pharm 2006;13:245-6.

17. Oche O, Sani I, Chilaka NG, Samuel NU, Samuel A. Pancreatic islet regeneration and some liver biochemical parameters of leaf extracts of vitex doniana in normal and streptozotocin-induced diabetic albino rats. Asian Pac J Trop Biomed 2014;4:124-30.

18. Vimala G, Gricilda Shoba F. A review on antiulcer activity of few indian medicinal plants. Int J Microbiol 2014;2014:519590.

19. Fatima S, Heena ST, Qureshi AS, Azharuddin M. Evaluation of antiulcer activity of $70 \%$ hydro-ethanolic leaf extract of Argemone mexicana Linn. in experimental rats. IOSR J Pharm 2016;6:41-50.

20. Souza FH, Jesus NZ, Gomes IF, Almeida LTJ, Morais, Lima GR, Barbosa, Filho JM. Tannins, peptic ulcers and related mechanisms. Int J Mol Sci 2012;13(3):3203-28.

21. Sayed AD, Fahmy RS, Soliman MA, Hussein SN. Antiulcerogenic efficacy of ethanolic extract Of Vitis vinifera leaves in rats. Int J Pharm Pharm Sci 2016;8:163-72

22. Pandey D, Joshi A, Hemalatha S. Anti-ulcer study of standardized ethanol root extract of Aganosma dichotoma and isolated ursolic acid. Int J Pharm Pharm Sci 2017;9:172-80. 